\title{
Probing the Comparative Bioefficacy of Allium sativum $L$. Bulb through Different Solvents
}

\author{
Fatma Hussain ${ }^{1 *}$, Muhammad Shahid ${ }^{1}$, Saba Zulfiqar ${ }^{2}$, Javaria Hafeez $^{1}$ \\ ${ }^{1}$ Department of Biochemistry, Faculty of Sciences, University of Agriculture, Faisalabad, Pakistan. \\ ${ }^{2}$ Department of Biochemistry, Faculty of Sciences, University Medical and Dental College, Faisalabad, \\ Pakistan.
}

*Corresponding author: Fatma Hussain, email: fatmauaf@yahoo.com; Phone number: 92-0302-6058018.

Received March 14 ${ }^{\text {th }}, 2021 ;$ Accepted May 17 ${ }^{\text {th }}, 2021$.

DOI: http://dx.doi.org/10.29356/jmcs.v65i4.1532

\begin{abstract}
Allium sativum (garlic), an aromatic bulbous plant is one of the most vital and oldest authenticated herbs which has been utilized from ancient times as a traditional medicine. A. sativum has cardioprotective, antimicrobial, anti-inflammatory, antidiabetic, antioxidant and anticancer properties due to a large range of phenolic compounds and sulfur containing compounds. The current study was conducted to assess the antioxidant chemistry, and numerous bioactivities of A. sativum bulbs extracts in different solvents. Ethanol fraction was the most active antioxidant and showed maximum total phenolic content $(16.18 \mathrm{~g} \mathrm{GAE} / 100 \mathrm{~g})$, total flavonoid content $(95.04 \mathrm{~g} \mathrm{CE} / 100 \mathrm{~g})$ and free radical scavenging activity $(75.50 \%)$. Methanol $(4 \%)$ fraction exhibited maximum antiglycation activity. Aqueous, $n$-hexane and ethyl acetate fractions exhibited maximal $(52 \%, 24 \%$ and $38 \%)$ inhibitions of alpha-amylase, alpha-glucosidase and acetylcholinesterase respectively. In an antimicrobial assay, ethanol (59.05\%) and chloroform $(72.92 \%)$ fractions showed maximum inhibition of Pasturella multocida and Staphylococcus aureus strains respectively. $n$-butanol and $n$ hexane fractions showed maximum (31 \%) antihemolytic activity and $(20 \%)$ thrombolytic activities respectively. A. sativum bulb extracts and fractions have noteworthy bio-efficacies that holds promise to be used as a source of natural drug to cure various disorders.
\end{abstract}

Keywords: Antioxidants; A. sativum; extraction solvents; flavonoid; antidiabetic; ethanol; phenols.

Resumen. Allium sativum (ajo), una planta bulbosa aromática, es una de las hierbas autenticadas más vitales y antiguas que se han utilizado desde la antigüedad como medicina tradicional. A. sativum tiene propiedades cardioprotectoras, antimicrobianas, anti-inflamatorias, anti-diabéticas, anti-oxidantes y anti-cancerígenas debido a una amplia gama de compuestos fenólicos y compuestos que contienen azufre. El estudio actual se llevó a cabo para evaluar la química antioxidante y numerosas bioactividades de extractos de rizoma de $A$. sativum en diferentes disolventes. La fracción de etanol tuvo la mayor actividad antioxidante y mostró un contenido fenólico total máximo (16.18 g GAE / 100 g), contenido total de flavonoides ( $95.04 \mathrm{~g} \mathrm{CE} / 100 \mathrm{~g})$ y actividad captadora de radicales libres $(75.50 \%)$. La fracción de metanol (4\%) exhibió la mayor actividad de antiglicación. Las fracciones acuosa, de n-hexano y de acetato de etilo inhibieron la actividad de alfa-amilasa, alfa-glucosidasa y acetilcolinesterasa, en $52 \%, 24 \%$ y $38 \%$ respectivamente. En el ensayo antimicrobiano, las fracciones de etanol (59.05\%) y cloroformo (72.92 \%) mostraron una inhibición máxima de las cepas de Pasturella multocida y Staphylococcus aureus, respectivamente. Las fracciones de n-butanol y n-hexano mostraron actividad anti-hemolítica (31\%) y trombolítica (20\%) respectivamente. Los extractos y fracciones 
de rizoma de A. sativum tienen bioeficacia notable con potencial de ser utilizadas como una fuente de fármaco natural para curar diversos trastornos.

Palabras clave: Antioxidantes; A. sativum; disolventes de extracción; flavonoide; antidiabético; etanol; fenoles.

\section{Introduction}

Garlic (Allium sativum L.), an aromatic herbaceous plant is used either as a raw vegetable for culinary purpose or as a natural medicine for various diseases.

A. sativum has many medicinal properties viz. cardioprotective, antimicrobial, anti-inflammatory, antidiabetic, antioxidant and anticancer due to a large range of phenolic compounds and sulfur containing compounds such as alliin, allicin, 1,2-vinyldithiin, allixin, s-allyl-cysteine [1,2] and thiosulfinate, one of the major organosulfur components containing cysteine sulfoxides and c-glutamylcysteines. Allicin and thiosulfonate are responsible for antioxidant potential of freshly chopped or crushed garlic bulb. Moreover, quercetin isolated from the $A$. sativum on interaction with vitamin $\mathrm{C}$ and $\mathrm{E}$ modifies the transferases and cytochrome P450 isozymes activities, while in vivo experiments demonstrated that three allyl sulfide constituents of garlic are involved in the regulation of factors associated with cell cycle and proliferation [3].

GLUT-4 gene expression, insulin up-regulation and alpha glucosidase inhibition play a chief role in the antihyperglycemic action of A. sativum. S-allyl cysteine sulfoxide stimulates the release of insulin from pancreatic beta cells. Phytoconstituents of $A$. sativum bulb protect the cell, enhance tissue protein synthesis, regulate bio-signaling molecules, transcription, cytokines synthesis, cell endurance and suppress redox stress [4].

Frequent intake of $A$. sativum boosts the internal antioxidant activities as well as downgrades the adverse effects of reactive oxygen species (ROS) by increasing the synthesis of antioxidants. Alliin inhibits the formation of ROS, prevents apoptosis by regulating the mitogen-activated protein kinase and reverses hyperglycemia. Traditional medicine literature is undoubtedly the basis for the invention of novel natural products $[5,6]$.

Although numerous medicinal aspects of $A$. sativum have already been studied, however, limited data is available regarding the biological activities of A. sativum extracts prepared in different polarity-based organic solvents. Therefore, the present study was undertaken to assess antioxidant, antidiabetic, cytotoxic, thrombolytic and antibiofilm activities of $A$. sativum bulb as these parameters are associated with several pathophysiological conditions such as redox stress, hypertension, diabetes mellitus, and infections.

The current study represents novel successive experimentations to probe the bioactivities of $A$. sativum bulb in six solvents along with the aqueous extract, an investigation setup that might not be used for this plant previously. The findings of research work may lead to explore new avenues within multifactorial treatment domains.

\section{Experimental}

\section{Plant sample and extracts preparation}

The plant material was procured from the local retail market. Shade drying was done for 7 days under normal air flow and ambient temperatures $\left(20 \pm 5^{\circ} \mathrm{C}\right)$ with no exposure to sunlight. Dried sample was ground to the fine powder. The plant species was authenticated by the Department of Botany, University of Agriculture, Faisalabad, Pakistan. The powdered sample $(300 \mathrm{~g})$ was extracted in methanol in a 1:6 ratio $(1 \mathrm{~g}$ of plant sample: $6 \mathrm{~mL}$ of methanol) by the incubation of sample in methanol for about 3 days at room temperature. After the filtration, residues were again extracted in the methanol for the next three days. Filtrate which was obtained 
after thrice extraction in methanol was dehydrated completely and put in storage at $-4{ }^{\circ} \mathrm{C}$. Methanolic extract $(145 \mathrm{~g})$ was dissolved in distilled water (1:10 ratio) and then partitioned in non-sequential manner by separating funnel into different solvents such as ethanol (60 g), chloroform (10 g), $n$-butanol (20 g), ethyl acetate (5 g), aqueous (10 g) and $n$-hexane (25 g) [7].

\section{Chemicals, reagents, enzymes}

Laboratory grade chemicals, reagents and enzymes from Sigma-Aldrich, Germany and USA were used. These included methanol, $n$-hexane, $n$-butanol, ethanol, ethyl acetate, chloroform, DPPH (2, 2-diphenyl 1-picrylhydrazyl, AlCl3, Potassium acetate, Folin- Ciocalteu reagent, Sodium carbonate, Glucose, Bovine Serum Albumin, $\mathrm{Na}_{2} \mathrm{HPO}_{4}$, Starch, Alpha glucosidase (G5003-100UN, Saccharomyces cerevisiae), Alphaamylase enzyme (porcine pancreatic), DNS (dinitro-salicylic acid) reagent, DTNB (5, 5-dithio-bis-2nitrobenzoic acid), acetylcholinesterase enzyme (C3389-2KU, Electrophorus electricus), acetylcholine iodide, physostigmine, metformin hydrocholoride, acarbose, ampicillin. Microbial strains were procured from the Institute of Veterinary Microbiology, University of Agriculture, Faisalabad, Pakistan.

\section{Antioxidant chemistry}

Antioxidant contents and activity were determined as described earlier [7]. For the estimation of total flavonoid content (TFC), test samples $+\mathrm{NaNO}_{2}+$ distilled water were mixed and later $\mathrm{AlCl}_{3}(300 \mu \mathrm{L})$ and $\mathrm{NaOH}(1 \mathrm{~mL})$ were added and then incubated at room temperature. Spectrophotometer was used to check the absorbance at $510 \mathrm{~nm}$. TFC was reported as g catechin equivalents $/ 100 \mathrm{~g}$ dry weight (methanol extract). For total phenolic content (TPC), $20 \%$ sodium carbonate was added following the mixing of all the extracts with the reagent. After that, the mixture was heated at $37^{\circ} \mathrm{C}$ and then cooled. Absorbance was measured at $750 \mathrm{~nm}$. Outcomes were depicted as $\mathrm{g}$ gallic acid equivalent/100 g dry weight (methanol extract). Free radical scavenging potential was evaluated by mixing the extracts with the $0.1 \mathrm{mM}$ solution of 2, 2-diphenyl-1picrylhydrazyl in methanol. Absorbance was measured at $515 \mathrm{~nm}$. Calculation: \% radical Scavenging $\left(\mathrm{IC}_{50}\right)=$ $100 \times\left[\mathrm{OD}\right.$ (control) $-\mathrm{OD}_{\text {(sample) }} / \mathrm{OD}$ (control) $]$.

\section{Anti-diabetic activity Antiglycation activity}

Antiglycation activity was assessed by following the protocol of Hussain et al [7]. D-glucose solution $(150 \mu \mathrm{L})$, bovine serum albumin $(150 \mu \mathrm{L})$, extract sample $(150 \mu \mathrm{L})$ were mixed. Mixture was incubated for ten days at $37^{\circ} \mathrm{C}$. Metformin was used a positive control. \% Inhibition: $100 \times($ control Optical Density - sample Optical Density (sample) / control Optical Density).

\section{Alpha-amylase inhibition assay}

For alpha amylase inhibition assay, $0.1 \mathrm{U} / \mathrm{mL}$ of $\alpha$-amylase (porcine pancreatic enzyme, Sigma Aldrich), sodium phosphate buffer solution (pH 6.9), starch (substrate) and test samples (100 $\mu \mathrm{L}$ each) were incubated at $25^{\circ} \mathrm{C}$ for 30 minutes and then the reaction mixture was heated for 5 minutes in boiling water bath after addition of 3, 5-dinitrosalicylic acid (DNS) to stop the enzyme catalysis. Absorbance was assessed at 540 $\mathrm{nm}$. Acarbose (synthetic inhibitor) was used as a positive control [7]. Inhibition was estimated as: [control

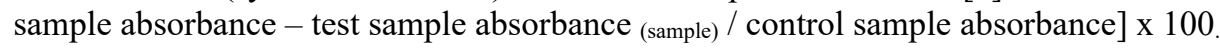

\section{Alpha-glucosidase inhibition assay}

In alpha-glucosidase inhibitory assay, $500 \mu \mathrm{L}$ of $0.1 \mathrm{M}$ phosphate buffer (pH 6.9), $100 \mu \mathrm{L}$ test samples and alpha-glucosidase solution $(1.0 \mathrm{U} / \mathrm{mL})$ were taken and incubated at $25^{\circ} \mathrm{C}$ for 10 minutes. In each test tube, $500 \mu \mathrm{L}$ of $5 \mathrm{mM}$ p-nitrophenyl- $\alpha$-D-glucopyranoside solution in $0.1 \mathrm{M}$ phosphate buffer (pH 6.9) was added after incubation. For 5 minutes the reaction mixtures were incubated at $25^{\circ} \mathrm{C}$ [7]. The absorbance was measured at $405 \mathrm{~nm}$ using a microplate reader. Methanol and acarbose were used as positive and negative controls respectively and the experiment was performed in duplicate. Percentage of $\alpha$-glucosidase inhibition was calculated as: $\%$ inhibition $=\left(1-\mathrm{A}_{\text {(sample) }} / \mathrm{A}_{(\text {control })}\right) \times 100$ 


\section{Acetylcholinesterase inhibition assay}

Acetylcholinesterase inhibitory activity was evaluated following the method of Hussain et al [7]. By dissolving the enzyme in $0.1 \mathrm{M}$ phosphate buffer, enzyme solution was prepared so that the concentration of the enzyme in the reaction mixture was about $0.0025 \mathrm{U} / \mathrm{mL}$ and this enzyme solution was kept in the iced water bath at $5{ }^{\circ} \mathrm{C}$. Then $30 \mu \mathrm{L}$ test sample, $2.81 \mathrm{~mL} 0.1 \mathrm{M}$ phosphate buffer, $100 \mu \mathrm{L}$ of DTNB (5,5-dithio-bis-2nitrobenzoic acid) stock solution and $30 \mu \mathrm{L}$ of AChE enzyme stock solution were mixed and incubated at $25^{\circ} \mathrm{C}$ for 5-10 minutes. After incubation, $30 \mu \mathrm{L}$ of substrate stock solution was added and absorbance was recorded at $412 \mathrm{~nm}$. As a positive control, $0.441 \mathrm{~g}$ amygra (physostigmine bromide) tablet (Tabros Pharma Pvt Ltd, Karachi, Pakistan) was dissolved in $10 \mathrm{~mL}$ distilled water and as a negative control methanol was used. Percentage of inhibition was calculated by using the following formula: \% inhibition $=\left[\mathrm{A}_{\text {(control) }}-\mathrm{A}_{\text {(sample) }} / \mathrm{A}\right.$ (control) $] \times 100$.

\section{Antimicrobial assay}

Garlic bulb extracts/fractions along with strains of bacteria (P. multocida, S. aureus) were combined in the nutrient medium, then placed in 96 well microtiter plates and were incubated for 1 day. Later, crystal violet was added following the washing of plates with phosphate buffer saline. Plates were air-dried and the dye bound to the adhered cells was solubilized with $100 \mu \mathrm{L}$ glacial acetic acid $(33 \% \mathrm{v} / \mathrm{v})$ per well. Absorbance was calculated at $630 \mathrm{~nm}$. Ampicillin was a positive control. Percentage (\%) biofilm inhibition: (OD control-OD sample/ OD control) $\times 100[7]$.

\section{Blood protection assays}

For the assessment of thrombolytic activity [8], blood was taken in the micro-centrifuge tubes and for the development of clot, these tubes were placed at room temperature. Serum was removed and then the weight of the clot was checked. Clot lysis was observed after the addition of extracts. Post-incubation, tube weight was checked to calculate weight difference upon clot disturbance [9]. Briefly, centrifugation of blood specimen was done at $1500 \mathrm{rpm}$, plasma (supernatant) was discarded and then PBS (phosphate buffer saline; $\mathrm{pH}$ 7.4) was used thrice to wash the pellets. After those cells were combined with the tested extracts and incubated. Absorbance was noticed at $576 \mathrm{~nm}$. Positive (citric acid) and negative (distilled water) controls were used.

For hemolytic activity, the cytotoxicity of the plant extract and its polar fractions was analyzed by the method of Powell et al. [10]. To separate the plasma from the cellular portion of blood, blood samples were collected and centrifuged at $1500 \mathrm{rpm}$ for three minutes. Plasma was discarded and with $5 \mathrm{~mL}$ of chilled $\left(4{ }^{\circ} \mathrm{C}\right)$ sterile isotonic phosphate buffer saline (PBS; $\left.\mathrm{pH} 7.4\right)$ the pellets were washed three times and centrifuged again at $1500 \mathrm{rpm}$ for 5 minutes and in normal saline a suspension of cells was prepared. On haemacytometer the washed RBCs were counted, maintaining the RBCs count to $7.068 \times 10^{8}$ cells per $\mathrm{mL}$ for each assay. Then $20 \mu \mathrm{L}$ of each fraction was taken in $2 \mathrm{~mL}$ Eppendorf tubes with $180 \mu \mathrm{L}$ diluted blood cell suspension and incubated at $37^{\circ} \mathrm{C}$ for 35 minutes. After 10 minutes the tubes were agitated, placed on ice for 5 minutes and again centrifuged for 5 minutes, $100 \mu \mathrm{L}$ supernatant was taken from the tubes and diluted with $900 \mathrm{~mL}$ chilled PBS, after centrifugation. After dilution, all tubes were placed on ice. Then into a 96 -well plate, $200 \mu \mathrm{L}$ of the mixture from each tube was added. For each assay $0.1 \%$ Triton X-100 was taken as a positive control, and PBS as a negative control. At $576 \mathrm{~nm}$ the absorbance was registered by a Bio TeK, $\mu$ Quant (BioTek, Winooski, VT, USA).

Percentage of hemolytic inhibition was calculated by the subsequent formula:

$\%$ Hemolysis inhibition $=(\mathrm{A}$ (sample) $-\mathrm{A}$ (negative control) $/ \mathrm{A}($ positive control) $-\mathrm{A}$ (negative control) $) \times 100$

\section{Statistical analysis}

Data were presented as mean \pm standard error (SE) or percentage and all measurements are average of triplicates. Statistical Packages for Social Sciences (SPSS, version 16.0) was used for the interpretation. 


\section{Results and discussion}

\section{Antioxidant chemistry}

Flavonoids and polyphenols are common natural antioxidants present in medicinal plants. TPC, TFC and DPPH assay examinations of all fractions are shown in table 1. Highest total flavonoids contents were found in ethanol $(95.04 \pm 0.212)$ and lowest were recovered in $n$-butanol $(9.59 \pm 0.019)$, as grams catechin equivalents $/ 100 \mathrm{~g}$ of plant. Likewise, the phenolic contents in different fractions were in the range of $1.84 \pm$ 0.015 to $16.18 \pm 0.034 \mathrm{GAE} \mathrm{mg} / \mathrm{g}$ plant. Maximum $(75.50 \%)$ radical scavenging activity was shown in the ethanol fraction.

Phenols have an aromatic ring along with at least one hydroxyl $(\mathrm{OH})$ group. S-allyl cysteine, one of the active constituents of garlic, is reported to possess antioxidant and anti-diabetic potentials. Major differences in findings of TPC, TFC contents and antioxidant activities among various extracts/fractions in current research may be due to varied number of phytoconstituents present in sample, extraction solvent nature and postextraction treatment [11].

Previously, TPC was calculated as $6.99 \pm 0.39 \mu \mathrm{g} \mathrm{GAE} / \mathrm{mg}$ in methanol extract of $A$. sativum bulbs [12] and extract of A. sativum exhibited TPC $562.6 \pm 1.92 \mathrm{mg} / 100 \mathrm{~g}$ GAE [13]. Flavonoids suppress the glucose level and increase hepatic glucokinase efficacy by triggering the release of insulin from pancreatic islets [14]. Range of antioxidant activity was 45.55 to 75.50 . Our results regarding antioxidant activity of $A$. sativum extracts are in accordance with literature data. Earlier, A. sativum bulb methanolic extract showed DPPH scavenging ability of $21.69 \pm 3.22 \mathrm{mg} / \mathrm{mL}$ [12]. Similarly, in another study fresh garlic exhibited 21.68 percent antioxidant inhibition [13]. It is suggested that $A$. sativum ingestion enhances internal antioxidant activities and decreases oxidative adverse effects. These effects are attributed due the presence of allicin $[5,6]$. However, some polysaccharides in raw A. sativum bulb also showed antioxidant efficacies [6].

\section{Antidiabetic Activity}

Advanced glycation end products (AGEs) are elevated due to few pathological circumstances such as oxidative stress (OS) in the patients of diabetes [15]. Such rise of AGEs prompt T lymphocytes destruction. In the current study, methanol fraction exhibited optimum (4\%) antiglycation effect. Whereas ascending trend of other fractionations was ethyl acetate $<$ chloroform $<n$-butanol $<$ aqueous $<n$-hexane $<$ ethanol $<$ methanol (Table 1). In a previous study A. sativum bulb ethanolic extract inhibited glycation process up to $26.1 \%$ [16]. Flavonoids, epicatechin, gallic acid and p-coumaric acid reduce the glycated derived free radicals [17]. Polyphenols play vital role as glycation inhibitors [18]. These polyphenols are present abundantly in natural products and work effectively in inhibition of Schiff base and Amadori products along with blockage of AGE receptors [19]. Inhibition of glycoside hydrolases and non-enzymatic glycation can be beneficial to reduce hyperglycemia and formation of AGEs. Rutin, ascorbic acid, aminoguanidine and quercetin are used as antiglycative agents because they have ability to cleave the AGEs induced chemicals cross links [15]. 
Table 1. Antioxidant chemistry and biochemical profile of Allium sativum L. bulb in extraction solvents of varying polarity.

\begin{tabular}{|c|c|c|c|c|c|c|c|c|}
\hline \multirow{2}{*}{ Activities } & \multicolumn{8}{|c|}{ Fractions } \\
\hline & Methanol & Ethanol & Ethyl acetate & $n$-hexane & n-butanol & Chloroform & Aqueous & Control \\
\hline \multicolumn{9}{|c|}{ Antioxidant profile } \\
\hline TFC & $72.96 \pm 0.03$ & $95.04 \pm 0.212$ & $11 \pm 0.021$ & $12.09 \pm 0.02$ & $9.59 \pm 0.019$ & $17.09 \pm 0.02$ & $20.77 \pm 0.03$ & - \\
\hline TPC & $12.08 \pm 0.29$ & $16.18 \pm 0.034$ & $3.5 \pm 0.071$ & $2.34 \pm 0.077$ & $1.84 \pm 0.015$ & $8.52 \pm 0.028$ & $14.72 \pm 0.06$ & - \\
\hline DPPH (IC 50$)$ & 74.68 & 75.50 & 46.59 & 51.59 & 45.55 & 55.41 & 67.70 & 90 \\
\hline \multicolumn{9}{|c|}{ Antidiabetic profile (\% inhibition) } \\
\hline Antiglycation & 4 & 3 & 0.15 & 2 & 0.49 & 0.34 & 0.69 & 53 \\
\hline \multicolumn{9}{|c|}{ Antimicrobial assay (\% inhibition) } \\
\hline S. aureus & 48.76 & 59.21 & 0 & 40 & 15.88 & 72.92 & 44.65 & 80.24 \\
\hline P. multocida & 55.68 & 59.05 & 0 & 28.10 & 19.88 & 36.94 & 50.65 & 82.24 \\
\hline
\end{tabular}

Data expressed as (mean $\pm \mathrm{SE}$ ) or percentage. All the extracts showed statistically significant results $p<0.05$.

TPC: total phenolic contents expressed as g gallic acid equivalents $/ 100 \mathrm{~g}$ dry weight; TFC: total flavonoid contents expressed as $\mathrm{g}$ catechin equivalents/100 g dry weight; DPPH: 2, 2-diphenyl 1-picrylhydrazyl. 
In the management of type 2 diabetes mellitus, alpha amylase inhibition is an important strategy [20] because its activity in the small intestine is correlated to the rise in levels of postprandial glucose. In the current study, aqueous fraction caused highest (52\%) inhibition values of alpha amylase, while the lowest inhibition was obtained by ethanolic extract $13 \%$ (Fig. 1). Previously, ethanolic extract of $A$. sativum bulbs had a notable inhibitory effect on alpha amylase from $10.27 \pm 0.48$ to $54.96 \pm 0.40 \%$ [39]. In another research [21], percentage alpha amylase inhibition by methanolic extract of $A$. sativum was $64.91 \pm 10.91 \%$, but in this study methanolic extract showed only $14 \%$ of inhibition. The potential of A. sativum bulbs to retard glucose absorption by restricting glucose hydrolyzing enzymes might be attributed to the presence of primary and secondary metabolites such as polysaccharides and phenols [20]. It has already been demonstrated that inhibitors of alpha amylase prevent carbohydrates breakdown and ultimately provide an effective way to lower postprandial hyperglycemia [22]. Another suggestion is that sulfur compounds present in A. sativum might be responsible for the alpha amylase inhibition [23]. All fractions showed less enzymatic inhibition than synthetic inhibitors and this result is not in accordance with previous finding [24] which show that some medicinal plants have greater alpha amylase inhibition than acarbose, the synthetic inhibitor.

Highest $\alpha$-glucosidase inhibition was shown by ethyl acetate (48\%) fraction of $A$. sativum bulbs. Enzyme inhibition shown by other extracts in ascending order was as: aqueous $<$ ethanol $<$ methanol $<n$-butanol $<$ chloroform $<n$-hexane (Fig. 1). Among the sulfur and phenolic compounds in A. sativum L., methionol and caffeic acid were predicted to be the most powerful inhibitors in a previous study, due to having more hydrogen bonds and hydrophobic interactions with the active site of $\alpha$-glucosidase [25].

Highest acetylcholinesterase (AChE) inhibition was shown by ethyl acetate extract (38\%). Other fractions exhibited inhibition in descending order as: methanol $>$ ethanol $>$ chloroform $>n$-hexane $>n$-butanol $>$ aqueous (Fig.1). In current research, AChE inhibition range shown by A. sativum extracts was 17-38 \%. Previously, essential oil extracted from A. sativum inhibited AChE activity up to $65.4 \%$ [26]. Essential oils also reduced the activity of $\mathrm{AChE}$ in hippocampal homogenates $[27,28]$. In conclusion, present data suggests that Allium sativum extracts and fractions are active inhibitors of AChE and hold promise to be used for the treatment of neurological manifestations.

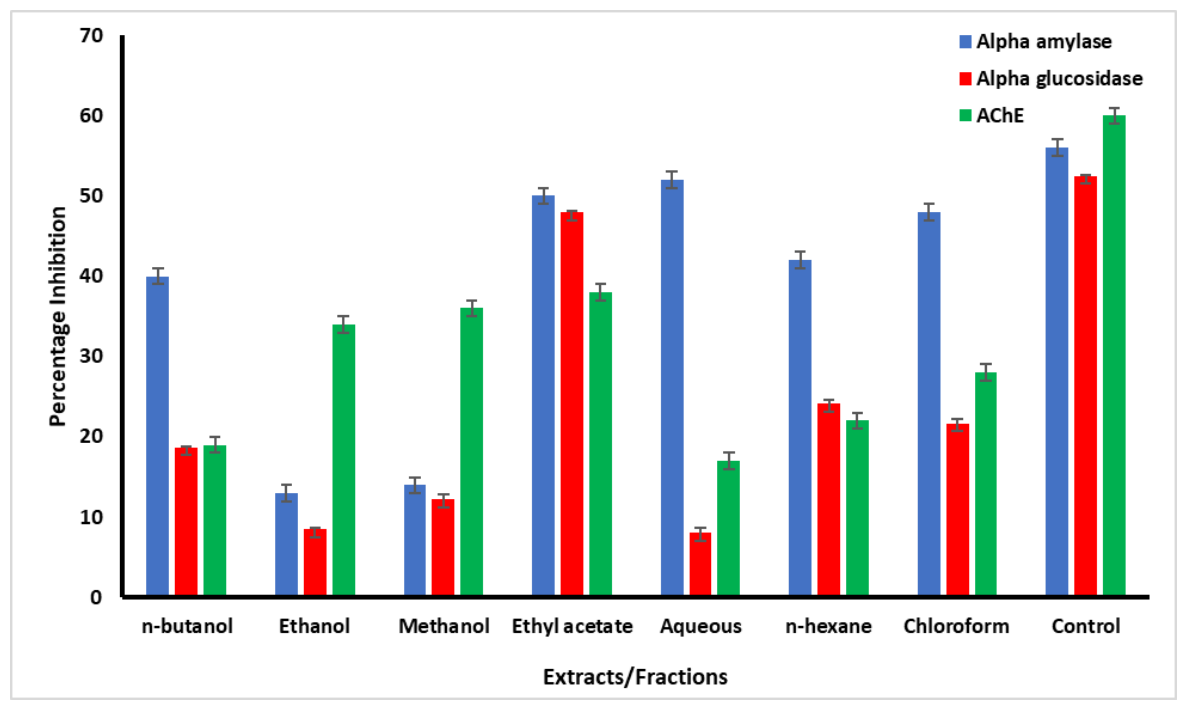

Fig. 1. Enzymes inhibition assays. Percentage inhibition of enzymes by plant extracts (methanol, aqueous)/fractions ( $n$-butanol, ethanol, ethyl acetate, $n$-hexane, chloroform). Results are presented as means \pm S.E $(n=3)$. AChE: acetylcholinesterase. 


\section{Antimicrobial assay}

A biofilm inhibition-based method was used and results indicated that ethanol and chloroform fractions of $A$. sativum bulbs showed highest inhibition (59.05\%) and (72.92 \%) against P. multocida (Fig. $2 \mathrm{~A})$ and $S$. aureus (Fig. 2C) respectively. Whereas ethyl acetate fraction did not inhibit growth of any of the strains (Fig. 2 B and 2D).

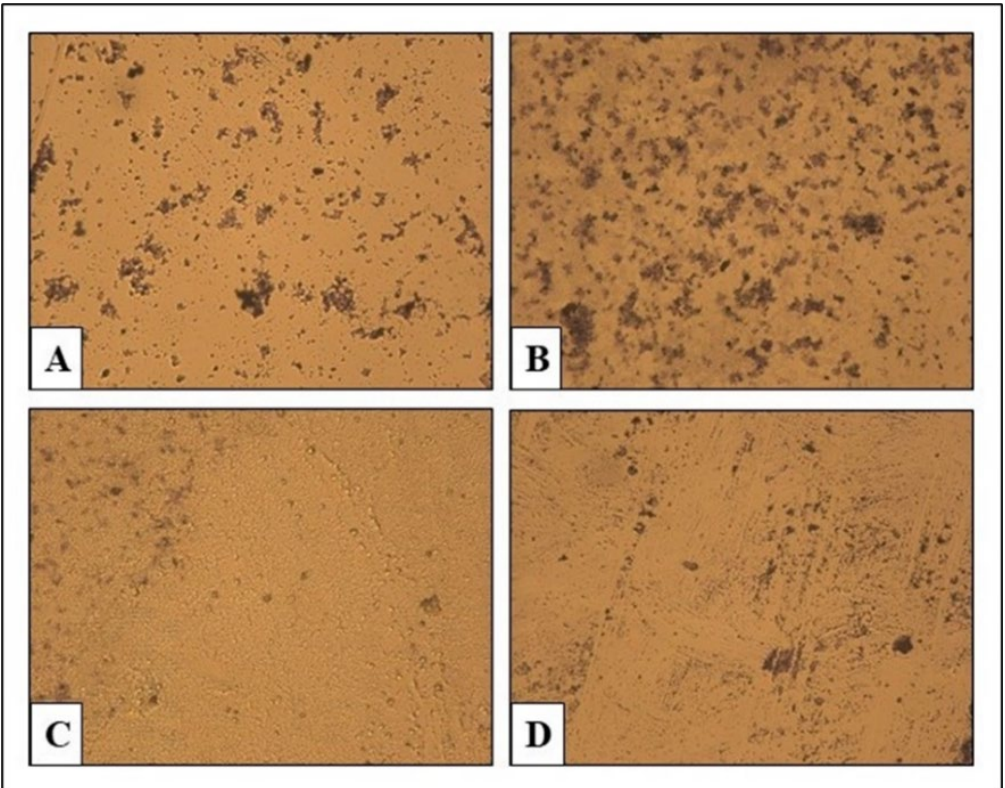

Fig. 2. Antibiofilm assay - highest and lowest growth inhibition. A, C: P. multocida and S. aureus growth inhibitions by ethanol and chloroform fractions. B, D: no growth inhibitory effects of ethyl acetate on both strains

Biofilm plays an essential role in antimicrobial resistance of the microbial pathogens [29]. Ethanol and methanol extracts of $A$. sativum bulbs were able to strongly prevent biofilm formation by Streptococcus pneumonia, Bacillus cereus and S. aureus up to $88.51 \%, 88.61 \%$ and $52.8 \%$ respectively [30] and these results are compatible with ours. A. sativum bulbs have antimicrobial activity against gram negative and positive bacteria [31]. Prominent bactericidal effect of A. sativum may be due to either growth inhibitory effects of allicin or its ability of restraining microbial adherence on surface, an important stage in biofilm development. Moreover, biofilm gene expression is down-regulated by allicin, thiosulfate group that reacts with the numerous cellular proteins in pathogens, suggesting the therapeutic efficiency of A. sativum on settled biofilm $[1,32,33]$.

\section{Blood protection activity}

In current study, anti-thrombolytic efficacy of different fractionations of A. sativum are in range of $9 \%$ to $20 \%$. Deep vein thrombosis, stroke and heart attack are among the cardiovascular conditions which alter the blood coagulation [34] and are modulated by antithrombogenic drugs [35]. Natural products have various antithrombogenic constituents that can be better therapeutic adjuncts than synthetic drugs as these have lesser side effects.

According to Batiha et al. [36], garlic formulations are extensively utilized to inhibit thrombosis. Previously, ethanolic and aqueous extracts of A. sativum exhibited significant fibrinolytic activity [37]. A study [38] revealed that A. sativum triggers the fibrinolytic activity by enhancing the activation of t-PA (tissue-type plasminogen activation) mediated plasminogen and also, reduces the thrombin formation by suppressing 
coagulation system. Diallyl trisulphide and diallyl disulphide exhibit less platelet thromboxane formation and antiplatelet activity than the placebo.

ROS alters the structure and function of biomolecules. Oxidative damage to lipid and protein moieties of red blood cell membranes are involved in hemolysis. However, numerous phytoconstituents are better antihemolytic agents and offer defense against cellular redox impairments [39]. Effect of plant extracts on blood cells is essential not only to assess the safety and efficacy of natural medicines but also to detect toxicity. In current study, $n$-butanol fraction exhibited the highest antihemolytic activity i.e. $31 \%$, followed by ethyl acetate fraction (28\%). Aqueous extract exhibited minimum (3\%) red blood cells protective potential. Current results can be justified by the fact that hydroxyl groups of the plant polyphenols scavenge the free radicals and protect blood cells $[40,41]$.

These inferences are in accordance with the previous reports that $A$. sativum protected erythrocytes against $\mathrm{H}_{2} \mathrm{O}_{2}$ induced osmotic lysis due to the sulfur containing allicin compound, which was found to have antioxidant activity $[42,43]$.

\section{Conclusion}

Therapeutic potentials of $A$. sativum bulb are well known worldwide as evidenced from available literature. In current study various solvent extracts and fractions of garlic bulb were probed to compare the bioefficacies. It is concluded that all the A. sativum bulb extracts and fractions exhibited variable but appealing bioactivities and $A$. sativum bulb can be used to ameliorate diverse pathophysiological conditions. However, in vitro assessments cannot be applied to in vivo settings. Further investigation involving structural characterization of bioactives and clinical trials is warranted.

\section{Acknowledgements}

The authors are thankful to Higher Education Commission (HEC), Pakistan for the financial support to the current research.

\section{References}

1. El-Saber, B.G.; Magdy, B.A.; Wasef, G.L.; Elewa, Y.H.; Al-Sagan, A.A.; El-Hack, A.; Mohamed, E.; Taha, A.E.; Abd-Elhakim, M.Y.; Prasad, D.H. Nutrients. 2020, 12, 872. DOI: https://doi.org/10.3390/nu12030872.

2. Badal, D.S.; Dwivedi, A.K.; Kumar, V.; Singh, S.; Prakash, A.; Verma, S.; Kumar, J. J. Pharmacogn. Phytochem. 2019, 8, 587-590.

3. Shang, A.; Cao, S.Y.; Xu, X.Y.; Gan, R.Y.; Tang, G.Y.; Corke, H.; Mavumengwana, V.; Li, H.B. Foods. 2019, 8, 246-276. DOI: https://doi.org/10.3390/foods 8070246.

4. Liu, Q.; Meng, X.; Li, Y.; Zhao, C.N.; Tang, G.Y.; Li, S.; Gan, R.Y.; Li, H.B. Compr. Rev. Food Sci. Food Saf. 2018, 17, 937-952. DOI: https://doi.org/10.1111/1541-4337.12355.

5. Dorrigiv, M.; Zareiyan, A.; Hosseinzadeh, H. Phytother. Res. 2020, 34, 1770-1797. DOI: 10.1002/ptr.6645.

6. Yan, J.K.; Wang, C.; Yu, Y.B.; Wu, L.X.; Chen, T.T.; Wang, Z.W. Food Chem. 2020, 339, 128081. DOI: https://doi.org/10.1016/j.foodchem.2020.128081. 
7. Hussain, F.; Akram, A.; Hafeez, J.; Shahid, M. Rev. Mex. Ing. Quím. 2021, 20, 173-184. DOI. https://doi.org/10.24275/rmiq/Bio1735.

8. Sabir, S.; Anjum, A.A.; Ijaz, T.; Ali, M.A. Pak. J. Med. Sci. 2014, 30, 389-395.

9. Hossain, M.S.; Chowdhury, M.E.H.; Das, S.; Chowdhury, I.U. J. Pharmacogn. Phytochem. 2012, 1, 99-104.

10. Powell, W.A.; Catranis, C.M.; Maynard, C.A. Lett. Appl. Microbio. 2000, 31, 163-68. DOI: https://doi.org/10.1046/j.1365-2672.2000.00782.x.

11. Ji, S.; Yoo, T.; Jin, S.; Ju, H.; Eom, S.; Kim, J.S.; Hyun, T. Rev. Mex. Ing. Quím. 2020, 19, 1453-1464. DOI: https://doi.org/10.24275/rmiq/Bio1186.

12. Rojo-Gutiérrez, E.; Buenrostro-Figueroa, J.; Natividad-Rangel, R.; Romero-Romero, R.; Sepulveda, D.; Baeza-Jimenez, R. Rev. Mex. Ing. Quím. 2020, 19, 385-394. DOI: https://doi.org/10.24275/rmiq/Alim1704.

13. Queiroz, Y.S.; Ishimoto, E.Y.; Bastos, D.H.M.; Sampaio, G.R.; Torres, E.A.F.S. Food Chem. 2009, 115, 371-374. DOI: https://doi.org/10.1016/j.foodchem.2008.11.105.

14. Oboh, G.; Ademiluyi, A.O.; Agunloye, O.M.; Ademosun, A.O.; Ogunsakin, B.G. J. Diet. Suppl. 2019, 16, 105-118. DOI: 10.1080/19390211.2018.1438553.

15. Magaji, U.F.; Sacan, O.; Yanardag, R. S. Afr. J. Bot. 2020, 128, 225-230. DOI: https://doi.org/10.1016/j.sajb.2019.11.024.

16. Ramkissoon, J.S.; Mahomoodally, M.F.; Ahmed, N.; Subratty, A.H. Asian Pac. J. Trop. Med. 2013, 2013, 561-569. DOI: https://doi.org/10.1016/S1995-7645(13)60097-8.

17. Khan, M.; Liu, H.; Wang, J.; Sun, B. Food Res. Int. 2020, 130, 108933. DOI: https://doi.org/10.1016/j.foodres.2019.108933.

18. Yeh, W.J.; Hsia, S.M.; Lee, W.H.; Wu, C.H. J. Food Drug. Anal. 2017, 25, 84-92. DOI: https://doi.org/10.1016/j.jfda.2016.10.017.

19. Matsabisa, M.G.; Chukwuma, C.I.; Chaudhary, S.K. S. Afr. J. Bot. 2019, 121, 121-127. DOI: https://doi.org/10.1016/j.sajb.2018.10.028.

20. Yan, J.K.; Wu, L.X.; Qiao, Z.R.; Cai, W.D.; Ma, H. Food Chem. 2019, 271, 588-596. DOI: https://doi.org/10.1016/j.foodchem.2018.08.012.

21. Nickavar, B.; Yousefian, N. Iran. J. Pharm. Res. 2009, 8, 53-57. DOI:10.22037/IJPR.2010.788.

22. Moses, Z.Z.; Haruna, G.S.; Odoh, O.J.; Danladi, G.J.; Sani, M.H. J. Biol. Res. Develop. 2020, 1, 1-14.

23. Wu, H.; $\mathrm{Xu}, \quad$ B. Int. J. Food Prop. 2014, 17, 599-609. DOI: https://doi.org/10.1080/10942912.2012.654562.

24. Ahmed, M.U.; Ibrahim, A.; Dahiru, N.J.; Mohammed, H.U.S. Clin. Med. Insights Endocrinol. Diabetes. 2020, 13, 1-5. DOI: https://doi.org/10.1177/1179551420963106.

25. Sadeghi, M.; Moradi, M.; Madanchi, H.; Johari B. In Silico Pharmacol. 2021, 9, 11. DOI: 10.1007/s40203-020-00072-9.

26. Ghajarbeygi, P.; Hajhoseini, A.; Hosseini, M.S.; Sharifan, A. J. Pharmacopuncture. 2019, 22, 231238. DOI: $10.3831 /$ KPI.2019.22.031

27. Jung, H.Y.; Lee, K.Y.; Yoo, D.Y.; Kim, J.W.; Yoo, M.; Lee, S.; Yoo, K.Y.; Yoon, Y.S.; Choi, J.H.; Hwang. I.K. BMC Complement. Altern. Med. 2016, 16, 431. DOI: 10.1186/s12906-016-1384-6.

28. Veerakumari, L.; Chitra, N. Int. J Sci. Res. 2016, 5, 883, 87.

29. Tewari, A.; Jain, B.; Dhamannapatil, P.S.; Saxena, M.K. EC Microbiol. 2018, 3, 71-77.

30. Mohsenipour, Z.; Hassanshahian, M. Jundishapur J. Microbiol. 2015, 8, 18971. DOI: 10.5812/jjm.18971v2. 
31. Ratthawongjirakul, P.; Thongkerd, V. Songklanakarin J. Sci. Technol. 2016, 38, 381-389.

32. Farrag, H.A.; Hosny, A.E.D.M.; Hawas, A.M.; Hagras, S.A.; Helmy, O.M. Saudi Pharm. J. 2019, 27, 830-840. DOI: https://doi.org/10.1016/j.jsps.2019.05.004.

33. Furner-Pardoe, J.; Anonye, B.O.; Cain, R.; Moat, J.; Ortori, C.A.; Lee, C.; Barrett, D.A.; Corre, C.; Harrison, F. Sci. Rep. 2020, 10, 12687. DOI: https://doi.org/10.1038/s41598-020-69273-8.

34. Mendes, T.C.; Lívero, F.A.R.; Souza, P.; Gebara, K.S.; Junior, A.G. Curr. Pharm. Des. 2020, 26, 176190. DOI: https://doi.org/10.2174/1381612825666191216125135.

35. Emon, N.U.; Kaiser, M.; Islam, I.; Kabir, M.F.I.; Mohammad, J.U.; Mifta, A.J.; Saifullah, M.T.; Abu, N.M.R.; Safaet, A.; Mohammad, N.I. J. Adv. Biotechnol. Exp. Ther. 2020, 3, 158-164. DOI: https://doi.org/10.5455/jabet.2020.d121.

36. Batiha, E.G.; Magdy, B.A.; Wasef, G.L.; Elewa, Y.H.; Al-Sagan, A.A.; El-Hack, A.; Mohamed, E.; Taha, A.E.; Abd-Elhakim, M.Y.; Prasad, D.H. Nutrients. 2020, 12, 872. DOI: https://doi.org/10.3390/nu12030872.

37. Ansari, F.; Mohammadi, N.S.; Naderi, G.; Sabet, M.S.; Karimi, A. Iran. J. Ped. Hematol. Oncol. 2011, $2,48-52$.

38. Alrumaihi, F. Pharmacogn. J. 2020, 12, 1463-74. doi: 10.5530/pj.2020.12.201.

39. Omale, J. and Alewo, I.M. Am. J. Phytomed. Clin. Ther. 2014, 2, 861-869.

40. Franco, R.R.; Zabisky, L.F.R.; Lima, J.J.P.; Alves, V.H.M.; Justino, A.B.; Saraiva, A.L.; Goulart, L.R.; Espindola, F.S. J. Ethnopharmacol. 2020, 261, 113132. DOI:10.1016/j.jep.2020.113132.

41.Karim, M.A.; Islam, M.A.; Islam, M.M.; Rahman, M.S.; Sultana, S.; Biswas, S.; Hosen, M.J.; Mozumder, K.; Rahman, M.M; Hasan, M.N. Clin. Phytoscience. 2020, 6, 1-12.

42. Azantsa, B.G.; Mbong, M.A.A.; Takuissu, G.R.; Matsinkou, R.S.; Djuikoo, I.L.; Youovop, J.F.; Ngondi, J.L.; Oben, J.E. J. Food Res. 2019, 8, 89. DOI: https://doi.org/10.5539/jfr.v8n4p89.

43. Suboh, M.S.; Bilto, Y.Y.; Aburjai, T.A. Phytother. Res. 2004, 18, 280-284. DOI: https://doi.org/10.1002/ptr.1380. 